УДК 349.2

https://doi.org/10.34142/23121661.2021.34.07

orcid. org/0000-0003-2727-5357

(С) Новіков Д.О., 2021

\author{
Д. О. Новіков
}

\title{
ДИФЕРЕНЦІАЦІЯ ПРАВОВОГО РЕГУЛЮВАННЯ ПРАЦІ ОСІБ, ЗАСУДЖЕНИХ ДО ПОЗБАВЛЕННЯ ВОЛІ
}

\section{Novikov \\ DIFFERENTIATION OF LEGAL REGULATION OF LABOR OF PERSONS SENTENCED TO IMPRISONMENT}

\begin{abstract}
Анотація. Автор досліджує проблематику диференціації правового регулювання праці осіб, засуджених до позбавлення волі. Автор підкреслює, що трансформація положень вітчизняного законодавства підтверджує входження правового регулювання праці осіб, засуджених до позбавлення волі до сфери дії трудового права. На переконання автора, наука трудового права повинна збільшити свою увагу до правового регулювання праці засуджених осіб, для того, щоб при створенні нормативно-правових актів у даному напрямку були враховані об’єктивні та суб'єктні критерії правового регулювання праці осіб, засуджених до позбавлення волі. Автор вважає, що існує необхідність не лише доктринального визнання необхідності повноцінної інтеграції до сфери дії трудового права праці осіб, засуджених до позбавлення волі, але й поглибленого вивчення окремих критеріїв диференціації правового регулювання праці цієї категорії осіб для вироблення оновленого законодавства, що забезпечить високий рівень захисту трудових прав засуджених та сприятиме їх ефективній ресоціалізації.
\end{abstract}

Ключові слова: суб'єктна диференціація, правове регулювання, праця, трудові відносини, засуджені до позбавлення волі.

Аннотация. Автор исследует проблематику дифференциации правового регулирования труда лиц, осужденных к лишению свободы. Автор подчеркивает, что трансформация положений отечественного законодательства подтверждает вхождение правового регулирования труда лиц, осужденных к лишению свободы, в сферу действия трудового права. По мнению автора, наука трудового права должна увеличить свое внимание к правовому регулированию труда осужденных, для того, чтобы при создании нормативно-правовых актов в данном направлении были учтены объективные и субъектные критерии правового регулирования труда лиц, осужденных к лишению свободы. Автор считает, что существует необходимость не только доктринального признания необходимости полноценной интеграции в сферу действия трудового права труда лиц, осужденных к лишению свободы, но и изучение отдельных критериев дифференциации правового регулирования труда этой категории лиц 
для выработки обновленного законодательства, что обеспечит высокий уровень защиты трудовых прав осужденных и будет способствовать их эффективной ресоциализации.

Ключевые слова: субъектная дифференциация, правовое регулирование, труд, трудовые отношения, осужденные к лишению свободы.

Abstract. The author explores the issue of differentiation of legal regulation of labor of persons sentenced to imprisonment. The author emphasizes that the transformation of the provisions of domestic legislation confirms the entry of legal regulation of labor of persons sentenced to imprisonment into the scope of labor law. According to the author, the science of labor law should increase its attention to the legal regulation of labor of convicts, so that when creating regulations in this area were taken into account objective and subjective criteria for legal regulation of labor of persons sentenced to imprisonment. The author believes that there is a need not only for doctrinal recognition of the need for full integration into the scope of labor law of persons sentenced to imprisonment, but also in-depth study of certain criteria for differentiation of legal regulation of this category of persons to develop updated safety of prisoner's labor rights and promote their effective resocialization.

Key words: subjective differentiation, legal regulation, labor, labor relations, prisoners.

Актуальність теми. Сучасна парадигма становлення та розвиток демократичної держави до засуджених до позбавлення волі повинна грунтуватись передусім не на каральному аспекті, не на їх подальшій прекарізації [1], а на ресоціалізації засуджених через їх адаптацію до нормального суспільного життя, в якому вони зможуть реалізуватись без подальшого вчинення кримінальних правопорушень. I саме тому виправлення засуджених до позбавлення волі не може грунтуватись на примусовій праці як це було у СРСР, коли й самі установи виконання покарань йменувались виправно-трудовими таборами чи виправно-трудовими колоніями. Відомо, що у цих радянських установах виконання покарань через примусове залучення до важкої та шкідливої праці засуджені отримували серйозні травми, невиліковні захворювання, а значне їх число гинуло на небезпечних роботах. Вважалось, що таке суворе та жорстоке ставлення до праці засуджених $\epsilon$ відповідною та пропорційною карою за скоєний злочин. Хоча здебільшого засуджені до позбавлення волі сприймались радянським керівництво в якості безоплатної робочої сили, яку можна максимально експлуатувати та легко замінювати новоприбулими засудженими. Ця позиція довгий час відображалась в радянському та українському законодавстві. Та й сьогодні ч. 3 ст. 6 Кримінально-виконавчого кодексу України закріплює, що суспільно корисна праця є одним 3 основних засобів виправ лення і самореалізації засуджених [2].

Суттєвим поштовхом до зміни цієї негативної ситуації стало прийняття Верховною Радою Закону України «Про внесення змін до Кримінальновиконавчого кодексу України щодо адаптації правового статусу засудженого до європейських стандартів» від 8 квітня 2014 року № 1186-VII [3], згідно 
якого у ч. 1 ст. 118 слова «повинні працювати» були замінені словами «мають право працювати». Відповідно, ч. 1 ст. 118 КВК виглядає наступним чином: «Засуджені до позбавлення волі мають право працювати. Праця здійснюється на добровільній основі на підставі договору цивільно-правового характеру або трудового договору, який укладається між засудженим та фізичною особоюпідприємцем або юридичною особою, для яких засуджені здійснюють виконання робіт чи надання послуг. Такі договори погоджуються адміністрацією колонії та повинні містити порядок їх виконання. Адміністрація зобов'язана створювати умови для праці засуджених за договорами цивільно-правового характеру та трудовими договорами». Водночас до сьогодні у КВК залишається положення, що «засуджені можуть залучатися без оплати праці лише до робіт з благоустрою колоній і прилеглих до них територій, а також поліпшення житлово-побутових умов засуджених або до допоміжних робіт із забезпечення колоній продовольством» (ч. 5 ст. 118). Наведена норма формує основу для зловживання з боку адміністрації установи відбування покарань можливістю залучення до примусової неоплачуваної праці засуджених до позбавлення волі за достатньо широким видом та характером робіт. Дане положення становить серйозну перепону для гуманного відношення до засуджених, праця яких використовується лише за їх бажанням. Вважаємо, що положення ч. 5 ст. 118 КВК мають бути переглянуті, а укладення трудового договору, його зміна та припинення повинні врегульовуватись Кодексом Законів про працю України із певними додатковими умовами, пов'язаними із виконанням покарання щодо засудженого. Наведені положення передбачають здійснення дослідження, пов’язаного із розкриттям гіпотези, що правове регулювання праці осіб, засуджених до позбавлення волі повинно здійснюватись у сфері трудового права, враховуючи фактори диференціації правового регулювання праці цих осіб.

Аналіз останніх досліджень. У юридичній науці вивчення новел щодо правового регулювання праці осіб, засуджених до позбавлення волі охоплюють передусім питання реалізації права на працю. У даному аспекті I. М. Лисенко зазначає, що «праця засуджених, на нашу думку, виконує функцію запобіжника проти деградації особистості, яка ймовірна через позбавлення волі». Водночас дослідник підкреслює, що «заміна існуючого в теперішній час у нашій державі обов'язку засуджених працювати на право працювати, тобто, відмова від примусової (обов'язкової) праці в місцях позбавлення волі, не може розглядатися як проста заміна обов'язку на право, яка сама по собі призведе до позитивних результатів» [4, с. 80]. О.I. Опанасенков робить важливий висновок, що «чим меншою є різниця між принциповими підходами до регулювання права на працю засуджених до позбавлення волі та вільних громадян у національному законодавстві, тим більш надійним виявлятиметься 
захист, охорона і забезпечення прав та законних інтересів учасників трудових відносин в УВП» [5, с. 265]. На думку О. Шкути, «суспільно корисна праця засуджених - це один із засобів і стимуляторів їх виправлення і ресоціалізації». При цьому дослідник акцентує увагу на тому, що в УВП наявні два види трудової діяльності: обов'язкова та необов'язкова. Як вказує вчений, «першу варто визнати не обов'язковою тому, що надано можливість вільного вибору (хочу отримувати гроші - іду працювати, не хочу - не йду). Друга - обов’язкова, бо передбачено безоплатну працю в межах установи виконання покарань (благоустрій установи, поліпшення житлово-побутових умов засуджених, заготівля продовольства тощо)» [6, с. 116]. Треба відзначити, що у даній тезі можна побачити залишки карального розуміння праці засуджених, а також визнання можливості здійснення примусу до праці через нав'язування засудженим особам обов'язкової праці.

Варто зазначити, що вищенаведені положення досліджень належать до предмету студіювання кримінально-виконавчого права, до представників якого сама ліквідація примусової праці засуджених є суттєвим кроком уперед у забезпеченні прав людини. Натомість вчені-трудовики наразі критично оцінюють дійсний стан додержання трудових прав та стандартів праці відносно осіб, засуджених до позбавлення волі. Ю.В. Кернякевич-Танасійчук пише, що «попри позитивні зміни, внесені у квітні 2014 року до Кримінально-виконавчого кодексу України, які уніфікували підхід законодавця до розуміння правової природи праці засуджених до позбавлення волі як права, не можна залишати поза увагою той факт, що праця засуджених завжди міститиме в собі обов'язковий характер і в чистому вигляді як право не може розглядатися. Такий висновок можна зробити 3 аналізу норм чинного кримінально-виконавчого законодавства, яке серед основних засобів виправлення та ресоціалізації засуджених називає суспільно-корисну працю, яка здійснює економічні, фізичні чи оздоровчі цілі та ціль виконання зобов'язань засудженим» [7, с. 38]. Л. Шумна відзначає, що «незважаючи на новації законодавства щодо залучення засуджених до праці з обов'язковості до визнання як конституційного права, праця все одно залишається одним з основних засобів впливу на засудженого. Головний наслідок наведених подвійних стандартів значення праці - це негативне ставлення до праці самих засуджених, іï сприйняття як елементу покарання, невиправданого примусу, що зводить нанівець виховну роль цієї діяльності» [8, с. 166]. Тому на дослідницькому рівні виникає потреба в науковому обгрунтуванні охоплення сферою дії трудового права правового регулювання праці осіб, засуджених до позбавлення волі.

Формулювання мети статmі. Автор має на меті дослідити проблематику диференціації правового регулювання праці осіб, засуджених до позбавлення волі. 
Виклад основного матеріалу статті. Трудові відносини є однорідними відносинами та не можуть розщеплюватись на декілька парадигм їх розуміння. Відповідно, не повинна існувати парадигма, що відмежовує правове регулювання праці осіб, засуджених до позбавлення волі, та усіх інших осіб, що працюють на підставі трудового договору на підприємствах, в установах, організаціях поза системи УВП. Якщо вбачати у цій парадигмі певний сенс, то ми маємо виходити з того, що в УВП досі застосовується примусова праця та така праця використовується поза волевиявленням та ініціативою осіб, засуджених до позбавлення волі. Це суперечить чинним положенням КВК, котрі не допускають примусової праці й передбачають здійснення праці осіб, засуджених до позбавлення волі, на підставі трудового договору.

3 іншої точки зору, ця хибна парадигма також зображувала наявність певних привілеїв у трудо-правовому статусі осіб, що працюють на підставі трудового договору на підприємствах, в установах, організаціях поза системи УВП - себто так званих звичайних працівників, якщо їх таким чином можна відділяти від тих, що працюють в УВП. Така дискримінація є не припустимою для трудових відносин: вона зводиться нанівець провідний принцип трудового права - принцип рівності, який, зокрема сформульований в Загальній декларації прав людини від 10 грудня 1948 р. в контексті того, що «кожна людина повинна мати всі права i всі свободи, проголошені цією Декларацією, незалежно від раси, кольору шкіри, статі, мови, релігії, політичних або інших переконань, національного чи соціального походження, майнового, станового або іншого становища» [9]. Аналогічне положення сформульоване і у ст. 24 Конституції України. Слід вказати, що до «іншого становища» необхідно віднести й перебування в УВП, адже таке перебування потенційно може бути фактором обмеження прав людини, що й відбувалось на законодавчому рівні в Україні до 2014 року. Конвенція № 111 Міжнародної організації праці про дискримінацію в галузі праці та занять 1958 р. містить приписи, згідно з якими дискримінацією у сфері праці слід вважати:

«а) будь-яке розрізнення, недопущення або перевагу, що робиться за ознакою раси, кольору шкіри, статі, релігії, політичних переконань, іноземного походження або соціального походження i призводить до знищення або порушення рівності можливостей чи поводження в галузі праці та занять;

b) будь-яке інше розрізнення, недопущення або перевагу, що призводить до знищення або порушення рівності можливостей чи поводження в галузі праці та занять» [10].

Аналогічно даному твердженню будь-яке розрізнення, недопущення, перевага встановлена щодо осіб, засуджених до позбавлення волі, у сфері праці $\epsilon$ неприпустимою через застосування до правового регулювання їх праці положень, котрі обмежують трудові права. 
Разом із тим необхідність додержання принципу рівності та відповідної єдності в трудовому праці допустимою є диференціація правового регулювання праці. Не можна не погодитись з О.І. Процевським, якій відзначав, що «єдність та диференціація правового регулювання є одним із способів досягнення мети рівності усіх працівників у правах, свободах і обов'язках незалежно від місця застосування здатності до праці» [11, с. 46]. О.М. Ярошенко зазначає, що «в основі диференціації лежать стійкі суспільні критерії, що визначають розходження в умовах праці і вимагають відображення в нормах права. Ці критерії є суспільними категоріями, держава враховує їх і надає їм значення» $[12$, с. 51]. Наука трудового права поділяє означені критерії диференціації на об’єктивні та суб'єктні. Об'єктивні критерії диференціації проявляються незалежно від того, ким виконується той або інший вид трудової діяльності. Вони залежать від умов, характеру праці тощо. У свою чергу, суб'єктні критерії диференційованого регулювання праці пов'язані з особою працівників, що тлумачиться в даному випадку в контексті окремих властивостей фізичної особи, яким трудове право надає спеціального обгрунтованого юридичного значення.

Що стосується диференціації правового регулювання праці осіб, засуджених до позбавлення волі, то ми маємо розглядати як об'єктивні, так і суб'єктні критерії. Об'єктивні критерії передусім походять із того, що праця засуджених здійснюється в умовах відбування покарання, що накладає свій відбиток на організацію їх праці та фіксацію відповідних спеціальних норм. При цьому щодо засуджених застосовується єдність правового регулювання праці, що обумовлює їх включення до сфери дії саме трудового права. Так, умови праці та оплата праці засуджених до позбавлення волі вже зараз врегульовуються трудовим законодавством. Згідно п. 2.2. Інструкції про умови праці та заробітну плату засуджених до обмеження волі або позбавлення волі, затвердженої Наказом Міністерства юстиції України від 7 березня 2013 року № 396/5 [13] (далі - Інструкція), «праця засуджених до обмеження волі регулюється законодавством про працю, за винятком правил прийняття на роботу, звільнення з роботи, переведення на іншу роботу».

Так, відповідно до п. 4.1. цієї Інструкції «для засуджених робочий тиждень не може перевищувати норму тривалості робочого часу, встановленого законодавством про працю. На безперервно діючих підприємствах, у цехах, дільницях, відділеннях і на деяких видах робіт, де за умовами виробництва (роботи) не може бути додержана встановлена для засуджених щоденна або щотижнева тривалість робочого часу, допускається підсумований облік робочого часу з тим, щоб загальна тривалість робочого часу за обліковий період не перевищувала норму тривалості робочого часу відповідно до законодавства». 
При цьому при правовому регулюванні праці осіб, засуджених до позбавлення волі, варто враховувати й суб'єктні критерії. Одна з перших дослідниць суб'єктних критеріїв диференціації правового регулювання у трудовому праві М.А. Покровська вважала, що таку диференціацію можна визначити як «диференціацію, засновану на розходженнях у правовому регулюванні трудових відносин за ознаками статі, віку та стану здоров'я працівників 3 метою конкретизації й спеціалізації «рівного права» стосовно нерівних суб'єктів» $[14$, c. 52$]$.

У сучасній науці трудового права визначається, що суб'єктні критерії диференціації правового регулювання можна поділити на загальні (зовнішні), передбачені для всіх суб'єктів певної групи (жінки, люди похилого віку, інваліди, неповнолітні), і спеціальні (внутрішні), які обумовлюють внутрішню диференціацію [15, с. 72]. Так, Інструкцією встановлюється важливі положення щодо умов праці неповнолітніх засуджених, вагітних жінок, засуджених до позбавлення волі, роботи засуджених у небезпечних та шкідливих умовах і т.п.

У свою чергу, внутрішня суб'єктна диференціація проявляється при взаємодії суб'єктних та об'єктивних критеріїв. У цьому контексті Г.С. Скачкова зазначила, що «об’єктивні та суб'єктні критерії диференціації діють, як правило, часто не ізольовано, а одночасно, нерідко доповнюючи один одного» [16, с. 32]. Л.В. Могілевський стверджує, що «суб’єктна диференціація завжди може бути розкрита більш повно лише при одночасному розгляді разом із яким-небудь об'єктивним чинником» [17, с. 12]. Себто суб'єктні критерії диференціації правового регулювання праці осіб, засуджених до позбавлення волі, можуть бути визначені та розкриті з точки зору їх детермінації об'єктивними критеріями, себто особливістю трудової діяльності в умовах відбування покарання.

Висновки. Трансформація положень вітчизняного законодавства підтверджує входження правового регулювання праці осіб засуджених до позбавлення волі до сфери дії трудового права. Тому наука трудового права повинна збільшити свою увагу до правового регулювання праці засуджених осіб, для того, щоб при створенні нормативно-правових актів у даному напрямку були враховані об’єктивні та суб'єктні критерії правового регулювання праці осіб, засуджених до позбавлення волі. Відповідно, існує необхідність не лише доктринального визнання необхідності повноцінної інтеграції до сфери дії трудового права праці осіб, засуджених до позбавлення волі, але й поглибленого вивчення окремих критеріїв диференціації правового регулювання праці цієї категорії осіб для вироблення оновленого законодавства, що забезпечить високий рівень захисту трудових прав засуджених та сприятиме їх ефективній ресоціалізації. 


\section{Література}

1. Новіков Д.О., Ландін В.В. Прекаріат як суб'єкт трудоправового захисту. Юридичний бюлетень. Вип. 13. 2020. С. 78-85; 2. Кримінально-виконавчий кодекс України від 11 липня 2003 року. URL: https://zakon.rada.gov.ua/laws/show/1129-15\#Text; 3. Про внесення змін до Кримінально-виконавчого кодексу України щодо адаптації правового статусу засудженого до європейських стандартів: Закон України від 08 квітня 2014 року № 1186-VII. URL: https://zakon.rada.gov.ua/laws/show/1186-18\#Text; 4. Лисенко М.I. Забезпечення права на працю засуджених в умовах ізоляції. Науковий вісник Міжнародного гуманітарного університету. Серія: Юриспруденція. 2015. Вип. 13 (2). С. 78-80; 5. Опанасенков О.І. Правове регулювання праці засуджених до позбавлення волі як засіб їх виправлення: сучасність і перспективи. Питання боротьби зі злочинністю. 2104. Вип. 27. С. 258-266; 6. Шкута О. Окремі питання залучення до праці засуджених до позбавлення волі. Наук. часопис Нац. акад. прокуратури Украӥни. 2016. Вип. 1. С. 111-118; 7. КернякевичТанасійчук Ю.В. Про правову природу праці засуджених до позбавлення волі. Науковий вісник Херсонського державного університету. Серія: Юридичні науки. 2014. Вип. 3. Т. 2. С. 37-40; 8. Шумна Л. Особливості праці засуджених до позбавлення волі: і право, i обов’язок. Вісник Пенітенціарної асоціащії України. 2018. Вип. 2. С. 160-167; 9. Загальна декларація прав людини від 10 грудня 1948 року. URL: https://zakon.rada.gov.ua/laws/ show/ 995_015\#Text; 10. Про дискримінацію в галузі праці та занять: Конвенція Міжнародної організації праці № 111 від 25 серпня 1958 року. URL: https://zakon.rada.gov.ua/laws/ show/ 993 161\#Text; 11. Процевський О.І. Окремі питання щодо єдності та диференціації правового регулювання трудових відносин. Збірник наукових пращь ХНПУ імені Г.С. Сковороди: Серія «Право». 2007. Вип. 9. С. 39-48; 12. Ярошенко О.М. Окремі питання єдності та диференціації правового регулювання праці. Актуальні проблеми науки трудового права в сучасних умовах ринкової економіки: Матеріали науково-практичної конференції; м. Сімферополь, 19-20 травня 2003 р. Х.: Нац.ун-т внутр.справ, 2003. С. 51-55; 13. Про затвердження Інструкції про умови праці та заробітну плату засуджених до обмеження волі або позбавлення волі: Наказ Міністерства юстиції України від 7 березня 2013 року № 396/5. URL: https://zakon.rada.gov.ua/laws/show/z0387-13\#Text; 14. Покровская М.A. Особенности правового регулирования труда женщин: автореф. дисс... канд. юрид. наук. Л., 1970. 20 с.; 15. Шульженко I.В. Диференціація правового регулювання праці за статевою ознакою. Право України. 2007. № 4. С. 71-74; 16. Скачкова Г.С. Расширение сферы действия трудового права и дифференциации его норм: автореф. дис... док. юрид. наук: 12.00.05. М., Институт государства и права, 2003. 58 с.; 17. Могілевський Л.В. Сдність і диференціація правового регулювання трудових відносин працівників органів внутрішніх справ України: автореф. дис... канд. юрид. наук: 12.00.05. Х., Харк. нац. ун-т внутр. справ, 2008. 22 с. 